\title{
Minimally invasive surgery for non-achalasia primary esophageal motility disorders is currently underused
}

\author{
Fernando A. M. Herbella' ${ }^{1}$, Francisco Schlottmann² \\ 'Department of Surgery, Federal University of Sao Paulo, Sao Paulo, SP 04037-003, Brazil. \\ 2Department of Surgery, Hospital Alemán of Buenos Aires, Buenos Aires C1118 AAT, Argentina.
}

\begin{abstract}
Correspondence to: Dr. Fernando A. M. Herbella, Department of Surgery, Escola Paulista de Medicina, Federal University of Sao Paulo, Rua Diogo de Faria 1087 cj 301, Sao Paulo, SP 04037-003, Brazil. E-mail: herbella.dcir@epm.br
\end{abstract}

How to cite this article: Herbella FAM, Schlottmann F. Minimally invasive surgery for non-achalasia primary esophageal motility disorders is currently underused. Mini-invasive Surg 2019;3:24. http://dx.doi.org/10.20517/2574-1225.2019.20

Received: 2 Jul 2019 Accepted: 16 Jul 2019 Published: 12 Aug 2019

Science Editor: Giulio Belli Copy Editor: Cai-Hong Wang Production Editor: Tian Zhang

\begin{abstract}
Surgical treatment for non-achalasia primary esophageal motility disorders is reserved for few situations. Proper selection of patients brings good outcomes with low morbidity, which makes surgical therapy an adequate therapeutic option. High resolution manometry reclassifies esophageal motility disorders. Interestingly, literature is scarce on surgical therapy for this new classification with per oral endoscopic myotomy as the leading treatment.
\end{abstract}

Keywords: Esophageal manometry, motility disorders, distal esophageal spasm, jackhammer esophagus

High resolution manometry reclassifies esophageal motility disorders based on the Chicago 3.0 classification $^{[1]}$. Even though there is a certain correspondence between previous and current classifications $^{[2]}$, a distinct nomenclature arrived based on newly developed - and putatively more objective and accurate - parameters. Thus, primary esophageal motility disorders (PEMD) are probably better diagnosed and evaluated.

Achalasia is surely the most understood PEMD. Other PEMD are not as well comprehended nor have defined therapy options. These other diseases defined by specific manometric pictures may occur as PEMD or secondary to gastroesophageal reflux disease (GERD $)^{[3]}$. If GERD is present, the motility abnormality is

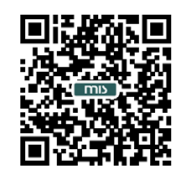


considered secondary, and treatment is directed toward reflux. In the absence of GERD, therapy is aimed at the modulation of the esophageal dysmotility with pharmacological agents or at the permeabilization of the gastroesophageal junction with endoscopic or surgical procedures ${ }^{[4]}$.

Surgical treatment for non-achalasia PEMD was reserved for few situations during the conventional manometry era. Cardiomyotomy (Heller's operation) and fundoplication are used for patients with hypertensive lower esophageal sphincter, diffuse esophageal spasm or nutcracker esophagus and obstructive symptoms ${ }^{[5,6]}$. Proper selection of patients is linked to good outcomes with low morbidity, which makes surgical therapy an adequate therapeutic option. Interestingly, literature is scarce on surgical therapy for this new classification with per oral endoscopic myotomy (POEM) as the leading treatment.

Ineffective esophageal motility is not treated by surgery. Hypertensive lower esophageal sphincter is no longer a PEMD according to Chicago 3.0.

There are no studies on Heller's myotomy for distal esophageal spasm (previously diffuse spasm) based on the new classification. Some case reports of POEM for distal spasm have been reported ${ }^{[7-9]}$ with multicenter studies encompassing a larger number of patients but always inferior to 20 in total ${ }^{[10]}$. Experience with the method is too short to draw conclusions. The same is true for jackhammer esophagus: no studies on Heller's myotomy and few case reports for $\mathrm{POEM}^{[9,11]}$. A recent systematic review compiling these small series $^{[12]}$ showed a clinical success of $90 \%$.

Esophagogastric junction outflow obstruction is an altered motility pattern contemplated by Chicago 3.0 classification. Most cases are associated to mechanical obstruction especially after operations in the area. Few cases are considered PEMD ${ }^{[13]}$. Interestingly, some cases treated by Heller's myotomy ${ }^{[13-15]}$ showed good outcomes while POEM did not show good results ${ }^{[16]}$.

In conclusion, Heller's myotomy and fundoplication are currently underused for the treatment of nonachalasia PEMD. POEM is the preferred treatment, but long-term results with larger series are still elusive.

\section{DECLARATIONS}

\section{Authors' contributions}

Made substantial contributions to conception and design of the study and performed data analysis and interpretation: Herbella FAM, Schlottmann F

\section{Availability of data and materials}

Not applicable.

\section{Financial support and sponsorship}

None.

\section{Conflicts of interest}

All authors declared that there are no conflicts of interest.

\section{Ethical approval and consent to participate}

Not applicable.

\section{Consent for publication}

Not applicable. 


\section{Copyright}

(c) The Author(s) 2019.

\section{REFERENCES}

1. Kahrilas PJ, Bredenoord AJ, Fox M, Gyawali CP, Roman S, et al. The Chicago Classification of esophageal motility disorders, v3.0. Neurogastroenterol Motil 2015;27:160-74.

2. Schlottmann F, Herbella FA, Patti MG. Understanding the Chicago classification: from tracings to patients. J Neurogastroenterol Motil 2017;23:487-94.

3. Herbella FA, Raz DJ, Nipomnick I, Patti MG. Primary versus secondary esophageal motility disorders: diagnosis and implications for treatment. J Laparoendosc Adv Surg Tech A 2009;19:195-8.

4. Patti MG, Herbella FA. Achalasia and other esophageal motility disorders. J Gastrointest Surg 2011;15:703-7.

5. Herbella FA, Tineli AC, Wilson JL Jr, Del Grande JC. Surgical treatment of primary esophageal motility disorders. J Gastrointest Surg 2008;12:604-8.

6. Schlottmann F, Shaheen NJ, Madanick RD, Patti MG. The role of Heller myotomy and POEM for nonachalasia motility disorders. Dis Esophagus 2017;30:1-5.

7. Albers D, Frieling T, Dakkak D, Kuhlbusch-Zicklam R, Töx U, et al. Peroral endoscopic myotomy (POEM) is effective in treatment of noncardiac chest pain caused by hypercontractile esophageal motility disorders: results of the POEM-HYPE-Study. Z Gastroenterol 2018;56:1337-42.

8. Orlandini B, Barret M, Guillaumot MA, Léandri C, Leblanc S, et al. Per-oral endoscopic myotomy for esophageal diverticula with or without esophageal motility disorders. Clin Res Hepatol Gastroenterol. 2019; doi: 10.1016/j.clinre.2019.03.013.

9. Sugihara Y, Harada K, Kato R, Yamauchi K, Takashima S, et al. Ten initial cases of peroral endoscopic myotomy for treatment of esophageal motility disorders at Okayama University Hospital. Acta Med Okayama 2018;72:99-104.

10. Khashab MA, Familiari P, Draganov PV, Aridi HD, Cho JY, et al. Peroral endoscopic myotomy is effective and safe in non-achalasia esophageal motility disorders: an international multicenter study. Endosc Int Open 2018;6:E1031-6.

11. Kandulski A, Fuchs KH, Weigt J, Malfertheiner P. Jackhammer esophagus: high-resolution manometry and therapeutic approach using peroral endoscopic myotomy (POEM). Dis Esophagus 2016;29:695-6.

12. Chandan S, Mohan BP, Chandan OC, Jha LK, Mashiana HS, et al. Clinical efficacy of per-oral endoscopic myotomy (POEM) for spastic esophageal disorders: a systematic review and meta-analysis. Surg Endosc 2019; doi: 10.1007/s00464-019-06819-6.

13. Lynch KL, Yang YX, Metz DC, Falk GW. Clinical presentation and disease course of patients with esophagogastric junction outflow obstruction. Dis Esophagus 2017;30:1-6.

14. Lin KH, Lee SC, Huang TW, Huang HK. Esophagogastric junction outflow obstruction-related functional chest pain treated using robotic-assisted thoracoscopic esophageal myotomy. J Thorac Dis 2017;9:E432-6.

15. Pereira PF, Rosa AR, Mesquita LA, Anzolch MJ, Branchi RN, et al. Esophagogastric junction outflow obstruction successfully treated with laparoscopic Heller myotomy and Dor fundoplication: first case report in the literature. World J Gastrointest Surg 2019;11:112-6.

16. Teitelbaum EN, Dunst CM, Reavis KM, Sharata AM, Ward MA, et al. Clinical outcomes five years after POEM for treatment of primary esophageal motility disorders. Surg Endosc 2018;32:421-7. 